\title{
Emissions from 3D Printers as Occupational Environmental Pollutants
}

\author{
Ilona PAVLOVSKA ${ }^{1}$, Žanna MARTINSONE ${ }^{2}$, Aneka KL̦AVIN̦A ${ }^{3}$, Lāsma AKŪLOVA ${ }^{4 *}$, \\ Linda PAEGLE ${ }^{5}$ \\ ${ }^{1-5}$ Institute of Occupational Safety and Environmental Health, Rīga Stradiņš University, Dzirciema iela 16, \\ Riga, Latvia
}

\begin{abstract}
While many people work remotely during the pandemic, three-dimensional (3D) printers are working to ensure the medical personnel and general public with the necessary specific materials. Ease of use, low cost, fast prototyping, and a wide range of materials are the advantages of 3D technology that can quickly adapt to specific needs in different application areas and result in increased popularity. The aim was to analyse the concentrations of particulate matter (PM) and volatile organic compounds (VOCs) emitted in 3D printing zone where printers are located throughout the room around the perimeter and where orthopaedics and designers develop models during their full shift. The average ultrafine particles (UFP) concentration level fluctuates from $4 \times 10^{3}$ to $26 \times 10^{3}$ particles $/ \mathrm{cm}^{3}$ that exceed the background level $\left(<3 \times 10^{3}\right.$ particles $\left./ \mathrm{cm}^{3}\right)$ during $8 \mathrm{~h}$-shift. Microclimate was evaluated as unsatisfied regarding permissible values for air quality at workplaces: air temperature exceeds permissible upper level $+25^{\circ} \mathrm{C}$, relative humidity was $21.5 \%$ and air velocity $\leq 0.05 \mathrm{~m} / \mathrm{s}$. The highest particles' number concentrations in the nano-scale range $(<0.1 \mu \mathrm{m})$ and significantly higher mass concentrations in the coarse particle range $(>2.5 \mu \mathrm{m})$ were detected. The median diameters of particle number $(0.019,0.014,0.015 \mu \mathrm{m})$ and mass concentrations $(4.394,4.433$, and $4.677 \mu \mathrm{m})$ were similar in all observed premises. Total VOC concentration was increased and specific substances such as toluene and formaldehyde $\left(0.56 \pm 0.1\right.$ and $\left.0.23 \pm 0.034 \mathrm{mg} / \mathrm{m}^{3}\right)$ were found at high concentration in comparison with indoor air quality recommendations.
\end{abstract}

Keywords - ELPI+; indoor air; inhaled particles; occupational exposure; PM2.5; PM10; PTrak; ultrafine particles; VOCs; 3D

\begin{tabular}{|llr}
\hline \multicolumn{2}{l}{ Nomenclature } & \\
ASA & Acrylate styrene acrylonitrile & - \\
ABS & Acrylonitrile butadiene styrene & - \\
ELPI+ & Electrical low-pressure impactor & - \\
FDM & Fused deposition modelling & - \\
3D & Three-dimensional & - \\
HIPS & High impact polystyrene & - \\
HPLC & High-performance Liquid Chromatography & - \\
MC & Mass concentration & - \\
NIOSH & National Institute for Occupational Safety \& Health & -
\end{tabular}

* Corresponding author.

E-mail address: lasma.akulova@rsu.lv 


\begin{tabular}{|lll|}
\hline nGEN & nGen amphora filament & - \\
NC & Number concentration & - \\
NYLON & Nylon filament yarn & - \\
OELs & Occupational exposure limits & - \\
VOC & Volatile organic compounds & - \\
PM & Particulate matter & - \\
PLA & Polylactic acid & - \\
PETG & Polyethylene terephthalate glycol & - \\
SLM & Selective laser melting & - \\
UFPs & Ultrafine particles & - \\
US EPA & United States Environmental Protection Agency & - \\
WHO & World Health Organization & - \\
\hline
\end{tabular}

\section{INTRODUCTION}

The popularity of three-dimensional (3D) printers, due to the Covid-19 pandemic, has only increased. At the beginning of the pandemic, there was a worldwide shortage of personal protective equipment, including face masks, gloves, eye protection, and clothing. There was also a shortage of respirators and medical parts for breathing aid devices and 3D printing became profitable. The advantages of this technology - ease of use, low costs, fast prototyping, and a wide range of materials - allowed rapid adaptation to specific needs [1][3].

During the Covid-19 pandemic sharing ideas online about 3D printing and 3D printed devices became easier. Various online platforms allowed consumers and hobbyists to meet with professionals and to participate in consultations with intensive and fast data exchange [1].

Due to the low manufacturing costs and the versatility of $3 \mathrm{D}$ technology, the $3 \mathrm{D}$ printing method has recently played a major role in medical equipment, implant material, cell printing and personal protection equipment manufacturing. By using 3D printers, it is possible to tackle existing donor problems by creating tissue or organ models [4], [5].

The printing process includes several actions and, according to the International Organization for Standardization, most methods can be put in seven categories: material extrusion, powder bed fusion, photopolymerization, material jetting, binder jetting, sheet lamination, and directed energy deposition. At the moment 3D printing equipment uses very different materials - both organic and inorganic compounds. Since the nature of printing equipment is very extensive, the range of materials used is also very large: a variety in alloys of plastics, metals, and many other materials [3], [6], [7].

Since 3D printing technology has become more popular in the industrial sector and among hobby classes, the safety issue has raised concerns, particularly regarding volatile organic compounds (VOC) and ultrafine particles (UFPs, particles less than $100 \mathrm{~nm}$ ) in the surrounding air. Recent studies have shown that there is a health risk associated with particles from the $3 \mathrm{D}$ printing process. For example, particles emitted by $3 \mathrm{D}$ printers can negatively affect air quality in the working environment or craft rooms and harm the health of the respiratory organs [8]-[10]. 
Workers using 3D printing technologies report health symptoms such as nasal congestion, rhinorrhoea as well as cough and itchiness of the nose, throat, or eyes [11]. The health effects of $3 \mathrm{D}$ printing are not fully known and there is a lack of research on the association between 3D printing techniques and health symptoms of the workers. As stated in an article by National Institute for Occupational Safety \& Health (NIOSH), the hazards of 3D printing are a mixture of well-understood, completely novel work environment risks, and the combination of the previous two, including psychological risks such as fatigue and stress as well as mechanical injuries like burns and electrical shock [6], [11], [12].

While there are no occupational exposure limits (OELs) for emissions from 3D printing and information on toxicological effects from 3D printer emissions are not completely understood, it asks for further studies to develop a system for identifying the health risks and categorizing emission rates from $3 \mathrm{D}$ printing processes. In addition, the increasing number of hours of 3D printing in household living areas raises the issue of possible emissions of UFPs and VOCs from printers that use polymeric materials into indoor air [10], [13], [14].

At the moment, the most common type of 3D printing technology for home hobbyists and commercial settings is the fused deposition modelling (FDM) 3D printers where acrylonitrile butadiene styrene (ABS) or polylactic acid (PLA) or acrylate styrene acrylonitrile (ASA) are the main polymers used in the printing of composites [1], [10], [14], [15]. For instance, the FDM printing process extrudes the filaments through a high temperature $\left(200^{\circ} \mathrm{C}\right)$ nozzle, causing the melting substance to emit VOCs and UFPs, as research results show higher temperature threads, such as ABS, produce more particles than threads with lower melting temperatures, such as PLA [15], [16].

Now the most commonly investigated filaments are PLA, ABS, high impact polystyrene (HIPS), and nylon filament yarn (NYLON), which in high-temperature 3D printing emit VOCs like styrene, caprolactam, lactide, ethylbenzene, xylenes, aldehydes, and others [16][18]. The difference in the emitted types of VOCs drives from filament material - styrene has been found from ABS and HIPS filaments [19]-[21], caprolactam from nylon-based filaments [21], [22], ethylbenzene [17], [21], [23], xylenes, and aldehydes from ABS [19], [22], [23] and acetone, as well as formaldehyde and toluene, from polyethylene terephthalate glycol (PETG) [10], [24]. Currently, the widespread use of PETG and nGen amphora filament (nGEN) filaments has not been sufficiently investigated. There were only two studies [25], [26] that evaluated the emission of UFPs and VOCs from PETG filament. No studies were found reporting the release of UFPs and VOCs during printing with printers using nGEN filament. Moreover, UFPs may be of particular importance for the toxicity of fumes emitted from the melting of some thermoplastics [9], [13].

The hazards and effects of dust on the employee depend on the size of the dust and the type of work to be performed. The most dangerous for employees is the dust of less than $5 \mu \mathrm{m}$, as these fine dust particles are capable of reaching the human respiratory tract, even alveoli. Particles reached alveolus are eliminated by macrophages or penetrate the blood vessels, afterwards, continue circulation and deposition in the body (see Fig. 1). Therefore, negative effects of particles to human health are related to their chemical composition, size, shape, persistence, solubility, etc. [27].

The particles of ultra-microscopic dust, if not absorbed or dissolved, are less hazardous as they converge into the uniform mass with the largest particles (aggregation occurs) and can be exhaled more easily. The dust of origin shall be classified into organic and inorganic [28][30]. 


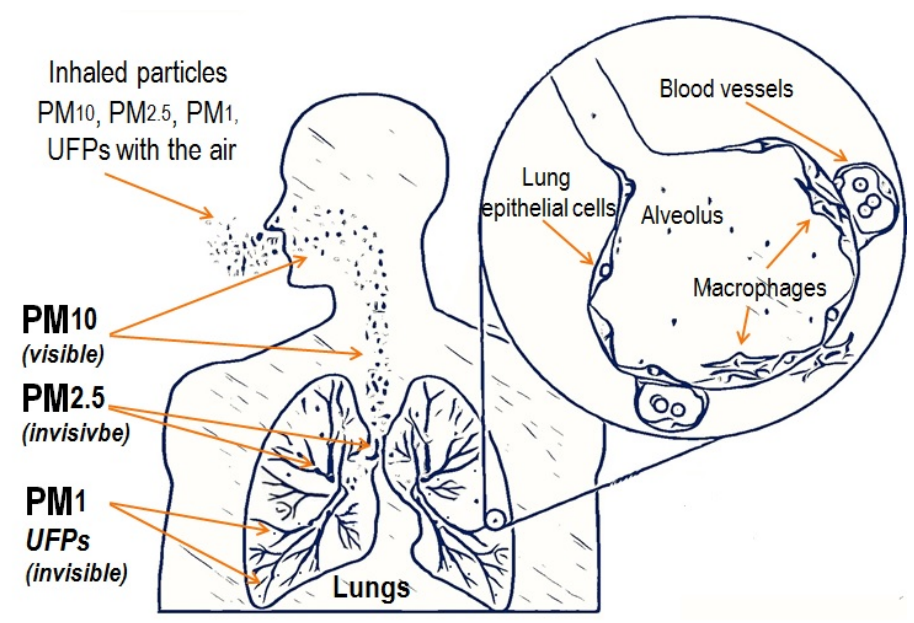

Fig. 1. How deep the inhaled particles get in the alveolar structures of the lungs (smaller than $\left.2.5 \mathrm{~mm}\left(\mathrm{PM}_{2.5}\right)\right)[27]$.

It is worth mentioning that chemical poisoning occurs when the occupational exposure limit value for OEL is exceeded, which means that the body is no longer able to discharge chemicals. Exactly why training of the service personnel of the $3 \mathrm{D}$ printing equipment in occupational health and safety is essential. Employees should know how to handle equipment correctly, have full knowledge of the materials to be used, and be trained for the correct use of personal protective equipment [6].

Overall, results highlight the problem of harmful compound emissions from the $3 \mathrm{D}$ printing process. New testing methods and further studies have been proposed for plastic thread manufacturers as indications of how to test their products and make them safer in areas of application [18], [23], [31]-[35].

To ensure a safe and healthy working environment for employees, the identification of workplace hazards and occupational health and safety measures in the $3 \mathrm{D}$ printing area at the theoretical level is not sufficient. Practical identification of workplace risks at company level is the cornerstone in selecting appropriate preventive measures and protect employees over a longer period of time.

\section{Methods AND Methodology}

In this study, the emissions from several 3D printer models such as Dimension 1200es (FDM, ABSplus thermoplastic), Objet350conex3 (Polyjet, ABS and resin type materials), Fortus $450 m c$ (FDM, ASA filament) and a hobby class printer - Makerboot $5^{\text {th }}$ Generation (FDM, ABS) - were analysed.

\subsection{Methods for Measuring Dust Particles}

Air samples for the $3 \mathrm{D}$ emission particles were taken using TSI P-Trak Ultrafine Particle Counter 8525 for particle count $\left(0\right.$ to $5 \times 10^{-5}$ particles $\left./ \mathrm{cm}^{3}\right)$, particle size diapason is from 20 $\mathrm{nm}$ to $>1000 \mathrm{~nm}$, maximum uncertainty $-10 \%$. The zero check test using adapted HEPA filter was provided before each measurements series. Measurements were done 1.1 meters above floor level and as close as possible to the employee's breathing zone to determine maximum concentration of contaminants that workers can inhale in a seated working position. 
No legislation has established or classified concentrations of dust and nanoparticles by number and surface area as occupational limit values, so the obtained results were compared with background data using the car parking backyard and small office premise as outdoor and indoor reference for comparison.

Real-time measurement data from one working shift ( $8 \mathrm{~h}$ including breaks) were collected by an electrical low-pressure impactor (ELPI+, Dekati Ltd). Measurements were performed approximately $1.1 \mathrm{~m}$ from the floor and as close to the worker as technically possible $(1-2 \mathrm{~m}$ from the operator as the ELPI+ measuring device limited closer access to the breathing zone of the employee as the instrument is not intended for personal sampling) [36].

The impactor classified particles on the so-called stages into 14 fractions by size in the range from $6 \mathrm{~nm}$ to $10 \mu \mathrm{m}$ (total uncertainty - $20 \%$ ) with a $9.87 \mathrm{lpm}$ sample flow rate using an outlet/inlet pressure, $40 \mathrm{mbar}$, and $1013.3 \mathrm{mbar}$, respectively. The ELPI+ each time before the measurement is needed zero check test carried out. The device is equipped with a pump providing filtered (HEPA filter) particle free air flow into the charger region at all stages. This enables zero check and adjustment of the electrometer zero levels [37].

The data were saved every second. All ELPI+ measurement files were transferred to Excel spreadsheets for further calculations [38].

In this study, we used the total number concentration $\left(\mathrm{NC}\right.$, particles $/ \mathrm{cm}^{3}$ ) and mass concentration $\left(\mathrm{MC}, \mathrm{mg} / \mathrm{cm}^{3}\right.$ ) of particulate matter (PM), and a summary of particulate matter $\left(\mathrm{PM}_{0.006}-\mathrm{PM}_{10}\right)$ distribution and concentration in the 3D printing office's premises.

\subsection{The Assessment of Chemicals and Measurement Organization}

Different groups of VOCs were identified - aldehydes (formaldehyde), aromatic hydrocarbons (toluene), and ketones (acetone).

To determine the concentration of chemicals in the indoor air, points for equipment installation were selected - the measuring equipment was installed in the workplace at the height of the breathing area as well as next to 3D printing equipment (see Fig. 2).

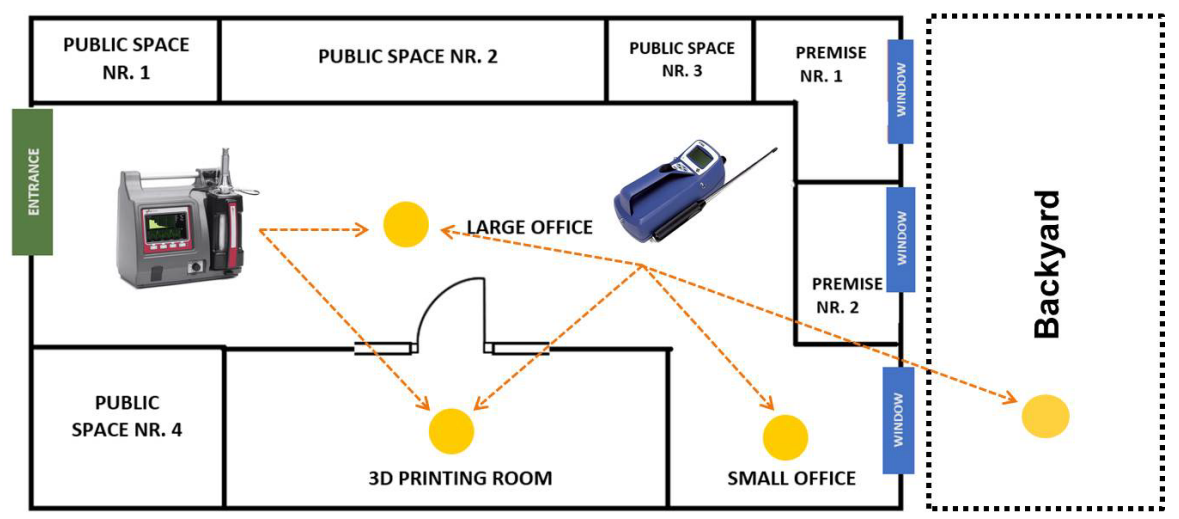

Fig. 2. Schematic figure of the measurement area.

Multiple samples were taken by point -3 for air samples and 5 to 25 samples per point for $\mathrm{CO}_{2}$ and microclimate measurements. The obtained results were then summed and divided to get an average value. The average quantity of each substance was determined for each room. Measurements were made in 3 different spaces - the large office, the small office (designer room, with an opened and closed window), and the 3D printing room where printing machines are located (with opened and closed doors towards the large office). Background 
measurements were performed in the backyard because the office's ventilation system did not work generally and the fresh air was taken through an open window. The backyard measurements were taken at the height of $1.5 \mathrm{~m}$ since the office windows are at the secondfloor level, where air pollution is slightly more diffused.

\subsection{Methods for Evaluating Chemical Compounds}

\subsubsection{Method for Evaluating VOCs}

Air samples for VOCs were taken in the breathing area of employees. The samples were collected throughout the working day, the employees were fitted with the low flow sampler 'Gilian LFS - 113DC' and the samples were taken on the small-activated coconut charcoal 'ORBO TM-32'.

The chemicals collected on charcoal were desorbed with $0.5 \mathrm{ml}$ of carbon disulphide. Samples were analysed on a VARIAN 3800 gas chromatograph with a CP8200 prophylactic sample delivery system. The analytical signal was obtained with a flame ionization detector (FID). Rxi-5 $(0.25 \mu \mathrm{m} \times 60 \mathrm{~m} \times 0.32 \mathrm{~mm})$ column was used for separation, $99.99 \%$ pure Helium as carrier gas was used to maintain the constant velocity mode with flow rate of 1.5 $\mathrm{mL} \mathrm{min}^{-1}$. Compounds were identified using specific reference standard from Sigma-Aldrich and the concentrations of individual compounds were determined according to standard calibration curves. Method accuracy was determined in validation procedure; all results have an expanded uncertainty, defined as the standard deviation multiplied by an overlap factor of 2 , giving a confidence level of $95 \%$.

\subsubsection{Method for the Evaluation of Aldehydes}

Air samples for aldehyde determination were taken with individual air sampling devices 'Gilian 3' using aldehyde sorption cartridge 'DNPH-Silica Cartridges' Aldehyde chromatographic analyses were performed by High-performance Liquid Chromatography (HPLC) on a Waters Alliance 2695, which has an automated sampling system for method observations. The NIOSH 2018 method was used to determine aldehydes [39].

\subsection{Method for Evaluating the Microclimate}

'Testo 400' probe was used to determine microclimate characteristics of indoor air; microclimate parameters were measured at a height of $1.1 \mathrm{~m}$ and $1.70 \mathrm{~m}$ from the floor taking employees' sitting position and standing position, respectively. Measurements were performed throughout the day, with a 1-hour time interval between measurements.

\section{RESUlts}

The average $\mathrm{PM}_{1}$ concentration level in the 3D printing office's premises fluctuated from $4 \times 10^{3}$ to $26 \times 10^{3}$ particles $/ \mathrm{cm}^{3}$ during $8 \mathrm{~h}$-shift measurements (see Table 1 ). The highest level was estimated in the $3 \mathrm{D}$ printing premise during active printing with Fortus $450 \mathrm{mc}$, Dimension 1200 es, and several Makerboot $5^{\text {th }}$ Generation $3 D$ printers at the same time using the $A B S p l u s$ thermoplastic, $A B S$ and $A S A$ filaments.

The lowest concentration was detected in the small office space, where indoor air exchange was provided not only with ventilation but also via open windows from the backyard side. Furthermore, the environmental background level of $\mathrm{PM}_{1}$ was evaluated at the backyard of the office building and measurements showed an average concentration: $8 \times 10^{3}$ particles $/ \mathrm{cm}^{3}$ 
(estimated range from $5 \times 10^{3}$ until $26 \times 10^{3}$, where the peak was reached due to traffic in the backyard).

\section{TABLE 1. SUMmARY OF RESUltS IN THE 3D PRINTING OFFICE}

\begin{tabular}{|c|c|c|c|c|c|c|c|}
\hline $\begin{array}{l}\text { The tested } \\
\text { premise of 3D } \\
\text { office }\end{array}$ & $\begin{array}{l}\mathrm{NC} \text { of } \mathrm{PM}_{1}{ }^{\mathrm{a}}, \\
\text { particles } / \mathrm{cm}^{3}\end{array}$ & $\begin{array}{l}\mathrm{NC} \text { of } \\
\mathrm{PM}_{0.006-10^{\mathrm{b}}}, \\
\text { particles } / \mathrm{cm}^{3}\end{array}$ & $\begin{array}{l}\mathrm{MC} \text { of } \\
\mathrm{PM}_{0.006-10^{\mathrm{b}}} \\
\mathrm{mg} / \mathrm{cm}^{3}\end{array}$ & $\begin{array}{l}\text { Total } \\
\text { VOCs, } \\
\mathrm{mg} / \mathrm{m}^{3}\end{array}$ & $\begin{array}{l}\text { Toluene, } \\
\mathrm{mg} / \mathrm{m}^{3}\end{array}$ & $\begin{array}{l}\text { Acetone, } \\
\mathrm{mg} / \mathrm{m}^{3}\end{array}$ & $\begin{array}{l}\text { Formaldehyde, } \\
\mathrm{mg} / \mathrm{m}^{3}\end{array}$ \\
\hline $\begin{array}{l}\text { Small office's } \\
\text { room } \\
\text { (with closed } \\
\text { windows) }\end{array}$ & $\begin{array}{l}4 \times 10^{3} \\
\text { (estimated } \\
\text { range: } \\
3 \times 10^{3}- \\
4 \times 10^{3} \text { ) }\end{array}$ & $\begin{array}{l}\text { Not } \\
\text { estimated }\end{array}$ & $\begin{array}{l}\text { Not } \\
\text { estimated }\end{array}$ & $0.51 \pm 0.1$ & $<0.52$ & $2.02 \pm 0.11$ & $<0.001$ \\
\hline $\begin{array}{l}\text { Large office's } \\
\text { room (with } \\
\text { opened door } \\
\text { to the 3D } \\
\text { printing room) }\end{array}$ & $\begin{array}{l}10 \times 10^{3} \\
\text { (estimated } \\
\text { range: } \\
6 \times 10^{3}- \\
13.6 \times 10^{4} \text { ) }\end{array}$ & & & & & & \\
\hline $\begin{array}{l}\text { Large office's } \\
\text { room (with } \\
\text { closed door } \\
\text { to the 3D } \\
\text { printing room) }\end{array}$ & $\begin{array}{l}5 \times 10^{3} \\
\text { (estimated } \\
\text { range: } \\
4 \times 10^{3}- \\
6 \times 10^{3} \text { ) }\end{array}$ & $26 \times 10^{3}$ & $0.233 \pm 0.046$ & $0.56 \pm 0.1$ & $<0.52$ & $2.2 \pm 0.44$ & $0.01 \pm 0.001$ \\
\hline $\begin{array}{l}\text { 3D printing } \\
\text { room } \\
\text { (with opened } \\
\text { door } \\
\text { to the large } \\
\text { office's room) }\end{array}$ & $\begin{array}{l}26 \times 10^{3} \\
\text { (estimated } \\
\text { range: } \\
13 \times 10^{3}- \\
74 \times 10^{3} \text { ) }\end{array}$ & $9 \times 10^{3}$ & $0.082 \pm 0.016$ & $0.64 \pm 0.13$ & $<0.52$ & $2.23 \pm 0.45$ & $0.23 \pm 0.034$ \\
\hline $\begin{array}{l}\text { 3D printing } \\
\text { room } \\
\text { (with closed } \\
\text { door } \\
\text { to the large } \\
\text { office's room) }\end{array}$ & $\begin{array}{l}5 \times 10^{3} \\
\text { (estimated } \\
\text { range: } \\
4 \times 10^{3}- \\
6 \times 10^{3} \text { ) }\end{array}$ & $16 \times 10^{3}$ & $0.083 \pm 0.016$ & $0.43 \pm 0.09$ & $0.61 \pm 0.12$ & $0.58 \pm 0.12$ & $<0.001$ \\
\hline $\begin{array}{l}\text { Recommended } \\
\text { values }\end{array}$ & $<3 \times 10^{3 \mathrm{c}}$ & $\begin{array}{l}\text { Not } \\
\text { established }\end{array}$ & $\begin{array}{l}0.015^{\mathrm{d}} \\
0.15^{\mathrm{e}}\end{array}$ & $0.3^{\mathrm{f}}$ & $0.26^{\mathrm{f}}$ & $590.0^{\mathrm{g}}$ & $0.1^{\mathrm{f}}$ \\
\hline
\end{tabular}

Notes:

$\mathrm{NC}$ - number concentration;

$\mathrm{MC}$ - mass concentration;

a - TSI P-Track Ultrafine Particle Counter 8525 for particle count $\left(0\right.$ to $5 \times 10^{-5}$ particles $\left./ \mathrm{cm}^{3}\right)$, particle size diapason is from $20 \mathrm{~nm}$ to $>1000 \mathrm{~nm}$;

b - Electrical low-pressure impactor (ELPI+, Dekati Ltd), which classify particles into 14 fractions by size in the range from $6 \mathrm{~nm}$ to $10 \mu \mathrm{m}$;

$\mathrm{c}-$ Average $\mathrm{PM}_{1}$ indoor air background level based to Laboratory of Hygiene and Occupational diseases data;

d - US EPA, 2012 [40];

e - Health Canada, 2010 [41];

$\mathrm{f}-\mathrm{WHO}, 2010$ [42];

g- NIOSH, 2014 [43].

The impact of $\mathrm{PM}_{1}$ background level was also detected inside the $3 \mathrm{D}$ printing office with natural ventilation via opened windows (located towards the backyard at the $2^{\text {nd }}$-floor level) and in the small office premise, where $\mathrm{PM}_{1}$ indoors concentration increased from $4 \times 10^{3}$ (with closed windows) to $6 \times 10^{3}$ (with opened windows, an average estimated range: $5 \times 10^{3}-8 \times 10^{3}$ ). In turn, $\mathrm{PM}_{10}$ (includes particles from $6 \mathrm{~nm}$ to $10 \mu \mathrm{m}$ ) $8 \mathrm{~h}$-shift measurements showed the 
highest $\mathrm{PM}_{10}$ mass and the number concentration in the large office's premise, but not in the $3 \mathrm{D}$ printing room. In addition, the results of the $3 \mathrm{D}$ printing room showed a decreasing trend in the number and mass concentration of particles, opening the door to a large office space. Besides particle mass' and number' concentrations also VOCs were identified and analysed. In general, total VOC concentration was increased and specific substances such as toluene, formaldehyde, and acetone were found at high concentrations. During measurements in the $3 \mathrm{D}$ printing room air temperature, humidity, air velocity, and carbon dioxide were monitored. The microclimate parameters were detected as follows: air temperature - from +25.0 to $+27.1{ }^{\circ} \mathrm{C}$, air humidity: from 21.0 to $22.0 \%$, air velocity from 0.01 to $0.05 \mathrm{~m} / \mathrm{s}$.

Table 2 shows the highest $\mathrm{NC}$ and MC in the large office's premise, as well as in the 3D printing room with a closed door to the large office's premise. The highest particles' number concentrations were detected at the nano-scale range $(<0.1 \mu \mathrm{m})$, but the significantly higher MC were detected as the opposite at the coarse particle range $(>2.5 \mu \mathrm{m})$. The median diameters of particle number $(0.019,0.014,0.015 \mu \mathrm{m})$ and mass $(4.394,4.433$, and $4.677 \mu \mathrm{m})$ concentrations were similar in all observed 3D printing office premises. Furthermore, rapid decreases of $\mathrm{NC}$ were observed above the $0.5 \mu \mathrm{m}$ size range, but $\mathrm{MC}$ were evaluated as double increasing above the $4 \mu \mathrm{m}$ size range. $\mathrm{PM}_{0.006}-\mathrm{PM}_{10}$ mass concentrations showed the higher $\mathrm{MC}$ directly in large office premises opposite evaluated 3D printing premise data, but when $\mathrm{PM}_{2.5}$ mass concentrations were calculated out from common mass data, and then similar trends were observed. In addition, Fig. 3(a), (b) and (c) show similar trends: more than $90 \%$ of detected particles by number distribution were at the nano-scale $(0.1 \mu \mathrm{m})$, but mass by particle size - rapid increase at particles size above $1 \mu \mathrm{m}$ (Fig. 3(d), 3(e), 3(f) in all observed premises of the $3 \mathrm{D}$ printing office.

TABLE 2. Summary of REAL-Time ELPI+ MeAsurements of $\mathrm{PM}_{0.006}-\mathrm{PM}_{10}$ Distribution AND CONCENTRATION IN THE 3D PRINTING OFFICE'S PREMISES.

3D PRINTING PREMise (With OPEnED DoOrs to THE LARGE RoOM)

\begin{tabular}{lllll}
\hline Stages, 1-14 & GMD** & $\mathrm{NC}, 1 / \mathrm{cm}^{3}$ & $\begin{array}{l}\mathrm{MC} \\
\mathrm{PM}_{0.006}-\mathrm{PM}_{2.5}, \\
\mathrm{mg} / \mathrm{m}^{3}\end{array}$ & $\begin{array}{l}\mathrm{MC} \\
\mathrm{PM}_{0.006}-\mathrm{PM}_{10}, \mathrm{mg}^{2} \mathrm{~m}^{3}\end{array}$ \\
\hline 1 & 0.0098 & 5261 & 0.0000 & 0.0000 \\
2 & 0.0218 & 1284 & 0.0000 & 0.0000 \\
3 & 0.0400 & 1365 & 0.0000 & 0.0000 \\
4 & 0.0711 & 723 & 0.0001 & 0.0001 \\
5 & 0.1230 & 349 & 0.0003 & 0.0003 \\
6 & 0.1996 & 224 & 0.0009 & 0.0009 \\
7 & 0.3142 & 68 & 0.0011 & 0.0011 \\
8 & 0.4824 & 24 & 0.0014 & 0.0014 \\
9 & 0.7596 & 7 & 0.0015 & 0.0015 \\
10 & 1.2495 & 3 & 0.0030 & 0.0030 \\
11 & 2.0167 & 1 & 0.0040 & 0.0040 \\
12 & 3.0169 & 1 & - & 0.0074 \\
13 & 4.4476 & 1 & - & 0.0169 \\
14 & 7.3122 & 1 & - & 0.0452 \\
\hline Total concentration & & 9311 & 0.0123 & 0.0821 \\
\hline CMD* $\mu$ m & & 0.019 & & 4.394 \\
\hline
\end{tabular}




\begin{tabular}{|c|c|c|c|c|}
\hline Stages, $1-14$ & GMD** & $\mathrm{NC}, 1 / \mathrm{cm}^{3}$ & $\begin{array}{l}\mathrm{MC} \\
\mathrm{PM}_{0.006}-\mathrm{PM}_{2.5}, \\
\mathrm{mg} / \mathrm{m}^{3}\end{array}$ & $\begin{array}{l}\mathrm{MC} \\
\mathrm{PM}_{0.006}-\mathrm{PM}_{10}, \mathrm{mg} / \mathrm{m}^{3}\end{array}$ \\
\hline 1 & 0.0098 & 12103 & 0.0000 & 0.0000 \\
\hline 2 & 0.0218 & 1567 & 0.0000 & 0.0000 \\
\hline 3 & 0.0400 & 827 & 0.0000 & 0.0000 \\
\hline 4 & 0.0711 & 721 & 0.0001 & 0.0001 \\
\hline 5 & 0.1230 & 398 & 0.0004 & 0.0004 \\
\hline 6 & 0.1996 & 209 & 0.0009 & 0.0009 \\
\hline 7 & 0.3142 & 78 & 0.0013 & 0.0013 \\
\hline 8 & 0.4824 & 27 & 0.0016 & 0.0016 \\
\hline 9 & 0.7596 & 7 & 0.0015 & 0.0015 \\
\hline 10 & 1.2495 & 2 & 0.0025 & 0.0025 \\
\hline 11 & 2.0167 & 1 & 0.0029 & 0.0029 \\
\hline 12 & 3.0169 & 1 & - & 0.0073 \\
\hline 13 & 4.4476 & 1 & - & 0.0200 \\
\hline 14 & 7.3122 & 1 & - & 0.0449 \\
\hline \multicolumn{2}{|c|}{ Total concentration } & 15942 & 0.0112 & 0.0833 \\
\hline $\mathrm{CMD}^{*}, \mu \mathrm{m}$ & & 0.014 & & 4.433 \\
\hline \multicolumn{5}{|c|}{ Large 3D office premise ${ }^{* * *}$} \\
\hline Stages, 1-14 & GMD** & $\mathrm{NC}, 1 / \mathrm{cm}^{3}$ & $\begin{array}{l}\mathrm{MC} \\
\mathrm{PM}_{0.006}-\mathrm{PM}_{2.5}, \\
\mathrm{mg} / \mathrm{m}^{3}\end{array}$ & $\begin{array}{l}\mathrm{MC} \\
\mathrm{PM}_{0.006}-\mathrm{PM}_{10}, \mathrm{mg} / \mathrm{m}^{3}\end{array}$ \\
\hline 1 & 0.0098 & 17715 & 0.0000 & 0.0000 \\
\hline 2 & 0.0218 & 5070 & 0.0000 & 0.0000 \\
\hline 3 & 0.0400 & 1374 & 0.0000 & 0.0000 \\
\hline 4 & 0.0711 & 927 & 0.0002 & 0.0002 \\
\hline 5 & 0.1230 & 490 & 0.0005 & 0.0005 \\
\hline 6 & 0.1996 & 283 & 0.0012 & 0.0012 \\
\hline 7 & 0.3142 & 113 & 0.0018 & 0.0018 \\
\hline 8 & 0.4824 & 44 & 0.0026 & 0.0026 \\
\hline 9 & 0.7596 & 17 & 0.0039 & 0.0039 \\
\hline 10 & 1.2495 & 7 & 0.0070 & 0.0070 \\
\hline 11 & 2.0167 & 2 & 0.0098 & 0.0098 \\
\hline 12 & 3.0169 & 2 & - & 0.0248 \\
\hline 13 & 4.4476 & 1 & - & 0.0567 \\
\hline 14 & 7.3122 & 1 & - & 0.1245 \\
\hline \multicolumn{2}{|c|}{ Total concentration } & 26046 & 0.0270 & 0.2329 \\
\hline \multicolumn{2}{|l|}{$\mathrm{CMD}^{*}, \mu \mathrm{m}$} & 0.015 & & 4.677 \\
\hline
\end{tabular}

\section{Notes:}

* - GMD: geometric mean diameter (aerodynamic) of particles collected at a particular stage, $\mu \mathrm{m}$

** - CMD: counted median diameter, $\mu \mathrm{m}$

$* * *$ - measurements include the end of working shift data (situation with open and closed doors to $3 \mathrm{D}$ printing premise) 


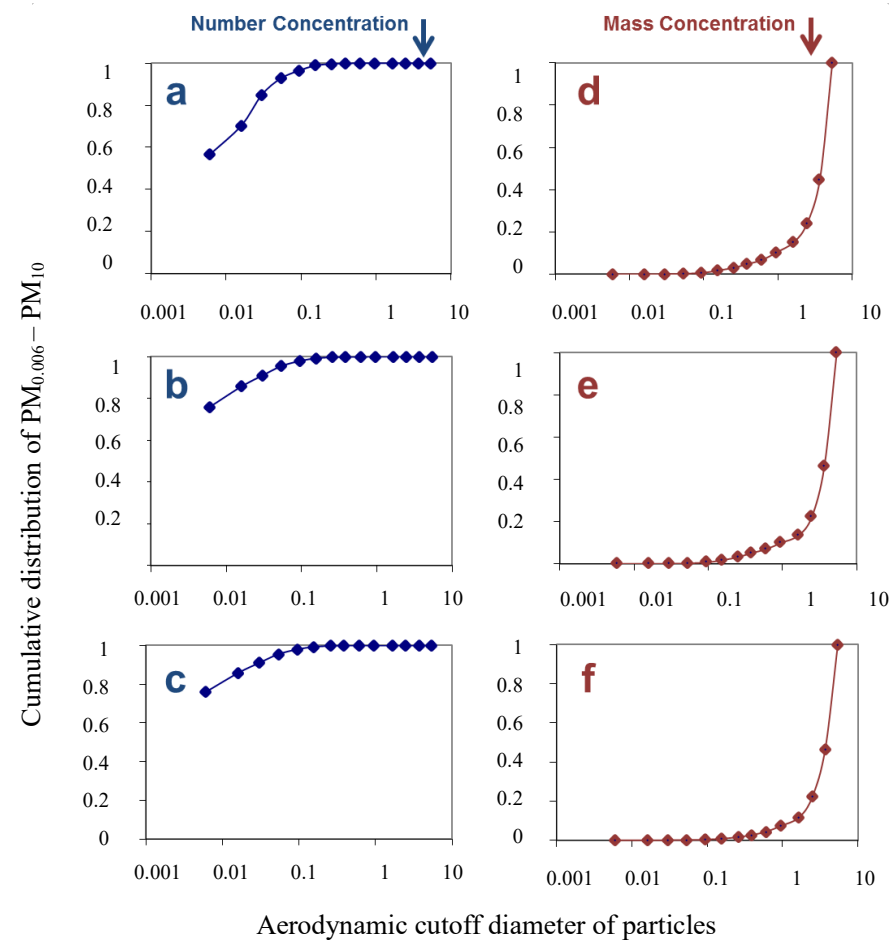

Fig. 3. Cumulative distribution of $\mathrm{PM}_{0.006}-\mathrm{PM}_{10}$ by number: a) in the $3 \mathrm{D}$ printing premise (with opened doors to the large room); b) in the 3D printing premise (with closed doors to the large room); c) in the large 3D printing office's premise. Cumulative distribution of $\mathrm{PM}_{0.006}-\mathrm{PM}_{10}$ by mass: $\mathrm{d}$ ) in the $3 \mathrm{D}$ printing premise (with opened doors to the large room); e) in the $3 \mathrm{D}$ printing premise (with closed doors to the large room); f) in the large $3 \mathrm{D}$ printing office's premise.

\section{Discussion AND CONCluSions}

The large office's premise was the most polluted based on 3D printing office preliminary data because of insufficient ventilation and direct connection with the 3D printing premise via the opened door. Therefore, the preliminary evaluation leads to assuming that the large office's premise could be defined as a 'blind spot' because of insufficient indoor air exchange and accumulation of all 3D printing emissions. Furthermore, estimated $\mathrm{PM}_{1}$ number concentrations exceed background levels for indoor air $\left(<3 \times 10^{3}\right.$ particles $\left./ \mathrm{cm}^{3}\right)$. Mass concentration for $\mathrm{PM}_{10}$ does not show any exceeding trends, but the highest $\mathrm{MC}$ was observed directly in the large office premise; a similar trend was observed for $\mathrm{PM}_{2.5}$ mass concentrations as well. $\mathrm{PM}_{2.5}$ mass concentrations were identified as close to ambient air quality standard value $-0.015 \mathrm{mg} / \mathrm{m}^{3}$, and exceeds it in some cases Also, similar median diameters of NC and MC show identical pollution sources in all 3D office premises. The fact regarding lack of appropriate ventilation system is based on air velocity data - lower than $0.05 \mathrm{~m} / \mathrm{s}$ (recommended: $0.05-0.15 \mathrm{~m} / \mathrm{s}$ ). In addition, this premise is located in the middle of the office without windows and local ventilations in comparison with the $3 \mathrm{D}$ printing premise. The improper ventilation system maintenance could be another reason for higher particle mass and number concentration levels pollution directly in the large office's premise at the end of the shift. Further, 3D printing office microclimate was evaluated as unsatisfied regarding permissible values stated in the Regulation of Cabinet of Ministers No 359. [44], 
for air quality at workplaces: air temperature exceeds permissible upper level $+25^{\circ} \mathrm{C}$, the relative humidity of air was lower than $30 \%$ and air velocity was lower than $0.05 \mathrm{~m} / \mathrm{s}$. Results of microclimate parameters characterize the situation at 3D printing room and large office as poor indoor air quality. Besides particle mass and number concentrations, also VOCs were identified and analysed. In general, total VOC concentration was increased and specific substances such as toluene and formaldehyde were found at high concentrations if being compared with indoor air quality recommendations. VOCs results include acetone, and since acetone is a natural compound of exhaled air, a specific recommended value for indoor acetone is not defined. In the future, more detailed qualitative (additional chemical substances should be evaluated) and quantitative (more sensitive methods for low concentration estimation) evaluation of VOCs based on 3D printer models and filaments usage are needed [3], [6], [7], [17], [19]-[23].

In addition, the $\mathrm{CO}_{2}$ level monitoring could be used as an indirect method to evaluate indoor air quality in the $3 \mathrm{D}$ printing office and to describe the efficiency of the ventilation system as well. 3D emissions accumulate in premises because of poor air quality, insufficient ventilation, and can potentially result in nonspecific health symptoms such as nasal congestion, rhinorrhoea; cough and itchiness of the nose, throat, or eyes, fatigue, headaches, etc. [11], [12]. Our results allow us to predict that workers might suffer from the following symptoms, however we did not have any data supporting this. Further research should be focused on medical check-up among employees of 3D printing enterprises.

A broader chemical analyses (e.g. caprolactam, ethylbenzene, xylenes) and ventilation system description should be gathered and analysed for accurate occupational chemical emission evaluation [17], [19]-[23] and the series measurement approach should be used in order to define exposure levels in $3 \mathrm{D}$ printing offices more accurately since the limitation of measurements is based on the lack of simultaneous measurements into different premises or workplaces as well as the stationarity of particle detection equipment [8]-[10]. The VOCs evaluation should be done more purposefully and selectively based on 3D printer types, processes and filaments, as well as more sensitive detection methods should be used in the following studies.

Special attention should be drawn towards the transformation of ordinary office premises to areas with potentially high chemical emissions during $3 \mathrm{D}$ printing or other similar processes should be done with appropriate adaptation of ventilation systems to reduce occupational exposure. The insufficiency of the ventilation system can promote the accumulation of $3 \mathrm{D}$ printing emissions in indoor air and it can also contribute to potential emission of the outdoor air.

It is considered that occupational risk assessment of chemical substances is based on mass concentration. Although the pollution source or sources in all premises is identical because of the similar median particle diameter for $\mathrm{NC}$ and particle MC, the preliminary data of this case study clearly shows the significant difference between particle mass and number concentrations, therefore $\mathrm{NC}$ should be taken into consideration for further evaluation of workers' health instead of MC [28]-[30].

Depending on whether the determination of the particles issued takes place in a special test chamber or in adapted room conditions, the results of other studies vary. Jinghai et al. notes that currently there are many types of $3 \mathrm{D}$ printers that are used for both industrial and domestic use, and they need to be classified more carefully. The number, mass and particle size emitted may depend on the filament composition, colour and the printer design characteristics itself. In the emission assessment study conducted using a chamber, the number of particles emitted from different filament types ranged from $3.62 \times 10^{10}$ to $2.33 \times 10^{11}$ 
particles $/ \mathrm{cm}^{3}$ [45]. In the Jensen et al. study, the number of particles identified in the various phases of metal 3D printing (SLM - Selective laser melting) ranged from $5 \times 10^{3}$ to $2.5 \times 10^{5}$ particles $/ \mathrm{cm}^{3}$. [46]. In another study the most popular filaments of $3 \mathrm{D}$ printers (ABS, PLA) were tested and the particles they issue. The results range from $2.9 \times 10^{2}$ to $1.6 \times 10^{5}$ particles $/ \mathrm{cm}^{3}$ (room background measurement $2.6 \times 10^{2}$ ) in a room measurement and from $7.4 \times 10^{2}$ to $12.8 \times 10^{6}$ particles $/ \mathrm{cm}^{3}$ for chamber measurements [47]. The study conducted by YU Zhou et al. in the clean room in various test scenarios identified from $2.5 \times 10^{7}$ particles $/ \mathrm{cm}^{3}$ to $4 \times 10^{7}$ particles $/ \mathrm{cm}^{3}$ [48].

In general, this study provides preliminary data regarding $3 \mathrm{D}$ printing work conditions and chemical emissions, therefore, additional 3D printing offices should be involved in the further research projects taking into account the rapid development of $3 \mathrm{D}$ manufacturing worldwide [4], [5].

\section{ACKNOWLEDGMENT}

We thank Dr Linda Matisāne, Rīga Stradiṇš university agency Institute of Occupational Safety and Environmental Health, for her writing assistance.

\section{REFERENCES}

[1] Wierzbicki J., et al. Additive manufacturing technologies enabling rapid and interventional production of protective face shields and masks during the COVID-19 pandemic. Advances in Clinical and Experimental Medicine 2020:29:10211028. https://doi.org/10.17219/acem/126296

[2] Aydin A., et al. 3D printing in the battle against COVID-19. Emergent Materials 2021:4:363-386. https://doi.org/10.1007/s42247-021-00164-y

[3] Ngo T. D., et al. Additive manufacturing (3D printing): A review of materials, methods, applications and challenges. Composites Part B: Engineering 2018:143:172-196. https://doi.org/10.1016/j.compositesb.2018.02.012

[4] Mardis N. J. Emerging Technology and Applications of 3D Printing in the Medical Field. Missouri Medicine 2018:368373.

[5] Sharma S., Goel S. A. 3D Printing and its Future in Medical World. Journal of Medical Research and Innovation 2018:3(1):e000141. https://doi.org/10.15419/jmri.141

[6] Roth G. A., et al. Potential occupational hazards of additive manufacturing. Journal of Occupational and Environmental hygiene 2019:16(5):321-328. https://doi.org/10.1080/15459624.2019.1591627

[7] The International Organization for Standardization. ISO/ASTM 52900:2015. Additive manufacturing. General principles. Terminology.

[8] Dunn K. L., et al. Reducing ultrafine particulate emission from multiple 3D printers in an office environment using a prototype engineering control. Journal of Nanoparticle Research 2020:22:112. https://doi.org/10.1007/s11051-02004844-4

[9] Bernatikova S., et al. Characterization of ultrafine particles and VOCs emitted from a 3D printer. International Journal of Environmental Research and Public Health 2021:18(3):929-944. https://doi.org/10.3390/ijerph18030929

[10] Gu J., et al. Characterization of particulate and gaseous pollutants emitted during operation of a desktop 3D printer. Environment International 2019:123:476-485. https://doi.org/10.1016/j.envint.2018.12.014

[11] Chan F. L., et al. Health survey of employees regularly using 3D printers. Occupational Medicine 2018:68(3):211-214. https://doi.org/10.1093/occmed/kqy042

[12] Chan F. L., et al. Emissions and health risks from the use of 3D printers in an occupational setting. Journal of Toxicology and Environmental Health - Part A: Current Issues 2020:83(7):11-19. https:/doi.org/10.1080/15287394.2020.1751758

[13] Afshar-Mohajer N., et al. Characterization of particulate matters and total VOC emissions from a binder jetting 3D printer. Building and Environment 2015:93(P2):293-301. https://doi.org/10.1016/j.buildenv.2015.07.013

[14] Stephens B., et al. Ultrafine particle emissions from desktop 3D printers. Atmospheric Environment 2013:79:334-339. https://doi.org/10.1016/j.atmosenv.2013.06.050

[15] Byrley P., et al. Particle emissions from fused deposition modeling 3D printers: Evaluation and meta-analysis. Science of the Total Environment 2019:655:395-407. https://doi.org/10.1016/j.scitotenv.2018.11.070

[16] Jeon H., et al. Effect of nozzle temperature on the emission rate of ultrafine particles during 3D printing. Indoor Air 2019:30(2):306-314. https://doi.org/10.1111/ina.12624

[17] Davis A. Y., et al. Characterization of volatile organic compound emissions from consumer level material extrusion 3D printers. Building and Environment 2019:160:10629. https://doi.org/10.1016/j.buildenv.2019.106209 
[18] Wojtyła S., et al. 3D printer as a potential source of indoor air pollution. International Journal of Environmental Science and Technology 2020:17:207-218. https://doi.org/10.1007/s13762-019-02444-x

[19] Stefaniak A. B., et al. Characterization of chemical contaminants generated by a desktop fused deposition modeling 3 dimensional printer. Journal of Occupational and Environmental Hygiene 2017:14(7):540-550. https://doi.org/10.1080/15459624.2017.1302589

[20] Potter P. M., et al. VOC Emissions and Formation Mechanisms from Carbon Nanotube Composites during 3D Printing. Environmental Science and Technology 2019:53(8):4364-4370. https://doi.org/10.1021/acs.est.9b00765

[21] Azimi P., et al. Emissions of Ultrafine Particles and Volatile Organic Compounds from Commercially Available Desktop Three-Dimensional Printers with Multiple Filaments. Environmental Science and Technology 2016:50(3):1260-1268. https://doi.org/10.1021/acs.est.5b04983

[22] Floyd E. L., Wang J., Regens J. L. Fume emissions from a low-cost 3-D printer with various filaments. Journal of occupational and environmental hygiene 2017:14(7):523-533. https://doi.org/10.1080/15459624.2017.1302587

[23] Kim Y., et al. Emissions of Nanoparticles and Gaseous Material from 3D Printer Operation. Environmental Science and Technology 2015:49(20):12044-12053. https://doi.org/10.1021/acs.est.5b02805

[24] Pinheiro N. D., et al. Paper-based optoelectronic nose for identification of indoor air pollution caused by 3D printing thermoplastic filaments. Analytica Chimica Acta 2021:1143:1-8. https://doi.org/10.1016/j.aca.2020.11.012

[25] Kagi N., et al. Indoor air quality for chemical and ultrafine particle contaminants from printers. Building and Environment 2007:42(5):1949-1954. https://doi.org/10.1016/j.buildenv.2006.04.008

[26] He C., Morawska L., Taplin L. Particle emission characteristics of office printers. Environmental Science and Technology 2007:41(17):6039-6045. https://doi.org/10.1021/es063049z

[27] Krug H. F., Wick P. Nanotoxikologie - eine interdisziplinäre Herausforderung (Nanotoxicology - an interdisciplinary challenge). Angewandte Chemie 2011:123(6):1294-1314. https://doi.org/10.1002/ange.201001037 (in German)

[28] Hashemi Habybabady R., et al. Effects of dust exposure on the respiratory health symptoms and pulmonary functions of street sweepers. Malaysian Journal of Medical Sciences 2018:25(6):76-84. https://doi.org/10.21315/mjms2018.25.6.8

[29] Brändli O. Sind inhalierte Staubpartikel schädlich für unsere Lungen? (Are inhaled dust particles harmful for our lungs?) Schweizerische medizinische Wochenschrift 1996:126(50):2165-2174. (in German)

[30] Yi J., et al. Emission of particulate matter from a desktop three-dimensional (3D) printer. Journal of Toxicology and Environmental Health - Part A: Current Issues 2016:79(11):453-465. https://doi.org/10.1080/15287394.2016.1166467

[31] Wojtyła S., Klama P., Baran T. Is 3D printing safe? Analysis of the thermal treatment of thermoplastics: ABS, PLA, PET, and nylon. Journal of Occupational and Environmental Hygiene 2017:14:80-85. https://doi.org/10.1080/15459624.2017.1285489

[32] House R., Rajaram N., Tarlo S. M. Case report of asthma associated with 3D printing. Occupational Medicine 2017:67(8):652-654. https://doi.org/10.1093/occmed/kqx129

[33] Hodgdon T., et al. Logistics of Three-dimensional Printing: Primer for Radiologists. Academic Radiology 2017:25(1):40-51. https://doi.org/10.1016/j.acra.2017.08.003

[34] Gümperlein I., et al. Acute health effects of desktop 3D printing (FDM) using ABS and PLA materials: an experimental exposure study in human volunteers. Indoor Air 2018:28(4):611-623. https://doi.org/10.1111/ina.12458

[35] Stefaniak A. B., et al. Evaluation of emissions and exposures at workplaces using desktop 3-dimensional printers. Journal of Chemical Health and Safety 2019:26(2):19-30. https://doi.org/10.1016/j.jchas.2018.11.001

[36] Pavlovska I., et al. Comparison of biological markers in aerosol-weighed workplaces. Journal of Nanoparticle Research 2019:21:138. https://doi.org/10.1007/s11051-019-4578-2

[37] Järvinen A., et al. Calibration of the new electrical low pressure impactor (ELPI+). Journal of Aerosol Science 2014:69:150-159. https://doi.org/10.1016/j.jaerosci.2013.12.006

[38] Pavlovska I., et al. Occupational exposure parameters for characterization of nanoparticulate matter toxicity: Metal versus wood processing. Process Safety and Environmental Protection 2016:102:230-237. https://doi.org/10.1016/i.psep.2016.03.018

[39] NIOSH Manual of Analytical Methods (NMAM), Fourth Edition, ALIPHATIC ALDEHYDES: METHOD 2018 [Online]. [Assessed 20.03.2021]. Available: https://www.cdc.gov/niosh/docs/2003-154/pdfs/2018.pdf

[40] United States Environmental Protection Agency: What are the Air Quality Standards for PM? [Online]. [Assessed 15.03.2021]. Available: https://www3.epa.gov/region1/airquality/pm-aq-standards.html

[41] Government of Canada: Guidance for fine particulate matter (PM2.5) in residential indoor air [Online]. [Assessed 20.03.2021]. Available: https:/www.canada.ca/en/health-canada/services/publications/healthy-living/guidance-fineparticulate-matter-pm2-5-residential-indoor-air.html

[42] World Health Organization: WHO guidelines for indoor air quality: selected pollutants. Copenhagen: WHO, 2010.

[43] The National Institute for Occupational Safety and Health (NIOSH): Table of IDLH values. Acetone [Online]. [Assessed 19.03.2021]. Available: https://www.cdc.gov/niosh/idlh/67641.html

[44] Cabinet of Ministers Republic of Latvia. Ministru kabineta noteikumi Nr. 359 Darba aizsardzības prasības darba vietās (Regulation of Cabinet of Ministers No 359. Labor protection requirements at workplaces.). Latvijas Vestnesis 2009:69. (in Latvian)

[45] Jinghai Y., et al. Emission of particulate matter from a desktop three-dimensional (3D) printer. Journal of Toxicology and Environmental Health, Part A 2016:79(11):453-465. http://dx.doi.org/10.1080/15287394.2016.1166467 
[46] Jensen A. C. Ø., et al. Nanoparticle Exposure and Workplace Measurements During Processes Related to 3D Printing of a Metal Object. Frontiers in Public Health 2020:8:778. https://doi.org/10.3389/fpubh.2020.608718

[47] Mendes L., et al. Characterization of Emissions from a Desktop 3D Printer. Journal of Industrial Ecology 2017:21(1):94106. https://doi.org/10.1111/jiec. 12569

[48] Zhoua Y., et al. Investigation of Ultrafine Particle Emissions of Desktop 3D Printers in the Clean Room. Procedia Engineering 2015:121:506-512. https://doi.org/10.1016/j.proeng.2015.08.1099 